\title{
Students' Errors in Simple Past Tense on Recount Text at Class IX SMPN 1 Lubukbasung
}

\author{
Etty Musfia ${ }^{1 *}$ and Muhd. Al Hafizh ${ }^{2}$ \\ I*Universitas Negeri Padang, Padang, Indonesia, ه(email), ettymusfia@yahoo.co.id \\ ${ }^{2}$ Universitas Negeri Padang, Padang, Indonesia, $ه$ (email), m_alhafizh@yahoo.com
}

\begin{abstract}
The purpose of this study is to describe the kinds of errors made by the students of class IX SMPN 1 Lubuk Basung in using simple past tense in writing a recount text. The design of this research was descriptive qualitative research with the students of grade IX who taught by the same teacher at grade VIII as the population. The instrumentation that used to collect the data in this research was a writing test. The researcher asks the students to write paragraphs based on the topic given. It found that the students had some errors in writing simple past tense on recount text. Based on the data analysis, types of students' errors were concerning with omission, addition (double marking, regularization, and small addition), misformation, and misordering. The errors made by the students were dealing with using verb be (was/were), past form of be, auxiliary did, article, preposition, and pronoun.
\end{abstract}

\section{Keywords: Students' Errors, Simple Past Tense, Recount Text}

\section{INTRODUCTION}

Dealing with educational aspect, the important of writing has been claimed as one of the skills that can determine the students' success in expressing their ideas into written form. Based on the Curriculum 2013 for the Junior High School, the students are expected to have ability using English in communication both in oral and written form. In Indonesia, writing skill is taught at Junior High School by genre based approach. The researcher focuses on recount text in this research. Recount text is taught to the students in the second year of Junior High School. Anderson (1998) states that recount text tells about past events. Since the recount text tells about the past events, its purpose is to tell the readers about what actually happened in the past by using past form of tense.

Students need to understand the language features and the generic structure of the text in constructing a text, especially recount. Ansyar (2014) explains that a recount text is organized by an orientation. This orientation is a part that consists of several events. The orientation of this text is usually followed by an evaluation or reorientation. Commonly, recount texts started with an orientation to introduce the background information that is needed to help readers' understanding to next part of the story. Regarding the language feautures, Derewianka (2011) explains specific participants, using simple past tense, using action verbs, using linking items to do with time are the language features of recount text.

Based on the researcher's experience in teaching and discussing with English teachers at SMPN 1 Lubukbasung, it seems to the researcher that most of the students face problems in writing. It is difficult to the students to write the correct sentence because they have lack of knowledge in English. They have lack of knowledge how to use to be in the past tense, past tense verb, pronoun, auxiliary did, and so on in English. They write the sentences in Indonesian first before writing them in English. They put their idea into their mother language when they want to write in English. They do not pay much attention to the grammar, word choice and the rules of writing in the target language. They sometimes make errors in using past form of to be and verb. They often put verb be (was/were) together with past form of verb after subject. They also use past form of verb after auxiliary in a sentence. They do not understand how to differentiate between regular verb and irregular verb.

According to Corder (1981), errors are caused by the learning process that is not complete yet, and the incompetency of learners in linguistic. This error is considered as something that can not be self-corrected. Furthermore, Richards (1974) states that an activity that is needed to reveal errors found in writing and speaking is error analysis. Error analysis is also the study that is aimed at studying the error made by the students of second and foreign language. In discussing error analysis, there are some purposes can be reached: to reveal the level of students' knowledge on a language, to analyze the process of students learning, and to acquire the information on the teachers' problems in preparing material for language teaching. The other explanation related to error analysis stated by Brown (2000). Brown defines error analysis as the process of observing, analyzing, and classifying the navigations of the second language rulers. It is also used to reveal the system that is operated by the learners. In fact, 
the students commit errors in language learning, and these errors can reveal the system operating with the students by process of observing, analyzing, and classifying. Thus, this study was aimed at describing the types of errors committed by the students at class IX of SMPN 1 Lubukbasung in the use of simple past tense of a recount text

\section{METHOD}

This research used descriptive qualitative research. The population of this research was the students of grade IX who taught by the same teacher at grade VIII before. They were class VIII 1, VIII 2, VIII 3, VIII 4, VIII 5 , and VIII 6 (6 classes). The sample was taken by making the rank of students' English mark. The rank obtained was categorized into three intervals classes; high, middle and low. All of the students in the middle class interval were the sample of this research. There were five steps in gathering the data: 1) Administering the test to the students; 2) Collecting the students' writing; 3) Reading all of the paragraphs had been written by the students; 4) Finding the errors made by the students by giving the codes; 5) Analyzing the types of errors. The collected data were analyzed properly by identifying the types of errors, classifying the errors, explaining the errors and evaluating the errors.

\section{RESULT AND DISCUSSION}

Based on the analysis of the data in this research, it was found that the students at grade IX at SMPN 1 Lubukbasung had some errors in writing simple past tense on recount text. It was based on the data of the types of errors, concerning with omission, addition (double marking, regularization, and small addition), misformation, and misordering. The errors made by the students were dealing with using verb be (was/were), past form of verb, auxiliary did, article, preposition, and pronoun.

The data showed us that the most errors were found in misformation. It was dealing with the using of verb be (was/were) and past form of verb. It was found that the students did errors here. Comparing with the errors on omission, it was found that the frequency of error on omission is lower than the frequency found on misformation. Dealing with errors in double marking, it was found that the frequency of errors made by the students was lower than omission. The next is about small addition, the frequency of errors found in small addition is lower than the errors on double marking. The next is misordering and regularization. It was found that the frequency of errors on misordering is higher than the frequency of errors on regularization. In short, it can be said that the students did various kind of error in using simple past on recount texts.
Table 1. Classification of Errors in Writing Simple Past Tense

\begin{tabular}{llcc}
\hline No & $\begin{array}{l}\text { Classification of } \\
\text { Errors }\end{array}$ & $\begin{array}{c}\text { Total Errors } \\
(396)\end{array}$ & $\begin{array}{c}\text { Frequency } \\
(\%)\end{array}$ \\
\hline & $\begin{array}{l}\text { Verb Be } \\
\text { (Was/Were) }\end{array}$ & 146 & 36.9 \\
\hline 2 & $\begin{array}{l}\text { Past Form of } \\
\text { Verb }\end{array}$ & 183 & 46.2 \\
\hline 3 & Auxiliary Did & 5 & 1.3 \\
\hline 4 & Article & 27 & 6.8 \\
\hline 5 & Preposition & 17 & 4.3 \\
\hline 6 & Pronoun & 18 & 4.5 \\
\hline & Total & 396 & 100 \\
\hline
\end{tabular}

Based on the data collected, it was found 396 total errors in all of students' writing simple past tense on recount text. Related to the total errors which was found, there were 146 of 396 (36.9\%) errors in using verb be (was/were), 183 of $396(46.2 \%)$ errors in using past form of verb, 5 of 396 $(1.3 \%)$ errors in using auxiliary did, 27 of $396(6.8 \%)$ errors in using article, 17 of $396(4.3 \%)$ errors in using preposition, and 18 of 396 (4.5\%) errors in using pronoun.

Table 2. The Percentage of Types of Errors

\begin{tabular}{clc}
\hline No & Types of Error & Frequency (\%) \\
\hline 1 & Omission & 23.48 \\
\hline 2 & Addition : & \\
\hline & a. Double Marking & 17.93 \\
\hline & b. Regularization & 0.76 \\
\hline & c. Small Addition & 8.08 \\
\hline 3 & Misformation & 45.71 \\
\hline 4 & Misordering & 4.04 \\
\hline & Total & \\
& & \\
\hline
\end{tabular}

Based on the research, there were four types of students' errors found in writing simple past tense on writing recount text. They are omission, addition (double marking, regularization, and small addition), misformation, and misordering, The data on the table above are the total percentages of all the components of errors. The components as stated before are; verb be (was/were), past form of verb, auxiliary did, article, preposition, and pronoun

Based on the finding above, it was found that the students had made various types of errors in writing simple past tense on recount text. In the case of the type of error in writing simple past tense, the most frequency of errors in simple past tense was found on misformation. Dealing with the highest frequent errors on misformation, it caused by two components; verb be (was/were), past form of verb. The first discussion is error in using verb be (was/were). There are six forms of verb be in English: am, is, are, was, were, and been. Nominal simple past tense should use verb be" was or were". It seems to us that students do not 
understand in using the correct form of verb be in simple past tense. They sometimes used verb be "was" for subject You, We or They, otherwise they used verb be "were" for subject I, She, He or It. Krohn (1997) states that the formulates of nominal sentence of simple past tense are; 1) Subject (I, She, He, It) should be followed by verb be "was"; 2) Subject (You, We, They) should be followed verb be "were".

The second one is errors in using past form of verb. The data showed us the errors in misformation in using past form of verb was the highest frequency. It occurred because English verbs have five forms, they are simple form (infinitive), third person singular, present participle, past tense (regular and irregular), and past participle (Wishon and Burks: 1980). Grammatically, the verb form in simple past tense is in past tense form (verb 2). It seems to us the students do not understand in choosing the suitable word. They are not able to use the proper form of simple past tense. Thus, it is found that the most error made by the students was in misformation.

The third is the errors on omission. It found there were two components in omission had high frequency. They were omission on verb be (was/were), past form of verb. It can be said that the students do not understand the function of verb be (was/were), past form of verb in simple past tense. They do not know that verb be (was/were) and past form of verb are the important elements in constructing simple past tense. So, it found many errors made by the students on omission.

It also found the omission on article. It seems to us, although the total of errors on omission of article was lower than omission on verb be (was/were) and past form of verb. It seems to us there found the students made errors on omission on article. Sometimes they omitted the article in the sentence. They did not understand the function or the position of the article. Harmer (2004) states that the articles in English; the, a, an are categorized as the determiners. The determiner is a class of word that is commonly placed at the beginning of a noun phrase or before a noun in a sentence.

The next is the errors on double marking. It found there were two components in double marking that had high frequency. They were double marking of verb be (was/were) and past form of verb. It can be said that the students do not understand the function of verb be (was/were) and past form of verb in simple past tense. They put verb be (was/were) and past form of verb together after subject in one sentence. They do not know that verb be (was/were), used only in nominal form and past form of verb in verbal form. It was also found, there was "did not" followed by past form of verb. So, it found many errors made by the students on double marking.

The next is the errors on small addition. It found there were two components on small addition that had high frequency. They were small addition on article and preposition. It can be said that still found the students added the articles and prepositions in the sentences, but the position and the function were not correct.

The next is misordering errors. It was found the misordering errors verb be (was/were). It is caused by the students' less knowledge on the correct position of verb be (was/were) in writing simple past tense. In positive and negative nominal English sentence, verb be should be put after subject, but in interrogative sentence, verb be should be put at the beginning of the sentence. In this case, some of the students do not understand that

Related to the above finding, it was found that students had various difficulties in expressing their idea in recount text especially in writing simple past tense. Dealing with simple past tense, it closes to past form of verb and verb be (was/were), auxiliary did, and so on. Dignen, at all (2007:47) explain that simple past tense is used to discuss about the past action or states often with the expression. Furthermore Wishon and Burks (1980:195), states that simple past tense is used to report a state or activity which can be ascribed to a definite past times.

Furthermore, the students made many errors in using verb be (was/were), especially on misformation. It is the highest frequency of errors they made. Verb be (was/were) has an important role in simple past tense. The difficulties found in students' writing in using verb be (was/were) is related to the research conducted by Ansyar 2012). The study found out that there were three types of errors had the highest frequency. They are omission of to be, using form of to be, and writing form of verb. The result of this research supports the finding of Ismahyuni (2004), who found some errors of students in using simple past tense on recount text. Related to this research, it was found some errors committed by the students in writing simple past tense. In this research found that the using of verb be (was/were) and past form of verb had the highest frequency of errors.

\section{CONCLUSION}

The errors in using verb be (was/were) and past form of verb are commonly found in students' writing recount text. Those errors of students in using verb be (was/were) and past form of verb are found in different types of errors. Although the errors found in students' writing simple past tense, it did not mean they made errors in all components. There found in some components that there were only few errors made by them. Therefore, they need more explanations about recount text, especially in writing simple past tense. Thus the further researchers need to conduct a research in exploring the causes of the students errors in using tense and the solution for solving those errors.

\section{ACKNOWLEDGMENTS}

I would like to offer heartiest gratitude to all those who support me in conducting this study. Firstly, I would like to say Alhamdulillah all praise to Allah SWT, for giving me strength and encouragement during all the moments in completing this research. Secondly, I would like to convey millions appreciations to who give me an opportunity to study at State University of Padang. Thirdly, I would like to express my sincere gratitude to my advisors Dr. Muhd. Al Hafizh, SS, MA. whose valuable guidance and expertise have guided me until the end of this study. Finally, I would like to thank my dear parents, husband, 
children, and family for giving me lots of support during this study.

\section{REFERENCES}

[1] Anderson, Mark \& Anderson, Kathy. 1998 Text Type in English. Australia: MacMillan Education.

[2] Ansyar. 2012. "Error in Using Simple past Tense in Recount Text Written by the Eight Grade of SMP Lab UM”. Unpublished Thesis. Malang. States University of Malang.

[3] Brown, H. Douglas. 2000. Principles of Language Learning and Teaching. New York: Longman

[4] Corder, Pit Stephen. 1981. Error Analysis and Interlanguage. Oxford: Oxford University Press.

[5] Derewianka, Beverly. 1990. Exploring How Text Work. Newtown: Australian Print Group

[6] Harmer, Jeremy. 2007. How to Teach English. Harlow: Longman

[7] Iswahyuni, Santi. 2014. "Error Analysis on the Use of Simple Past Tense in Recount Text of the 8th Grade Students of SMPN 3 Probolinggo". Unpublished Thesis. Brawijaya University.

[8] Wishon, George and Julia M. Burks. 1980. Let's Write English. New York: Litton Education 